\title{
Os Sujeitos de um Processo: A experiência de jovens em processo de fracasso escolar
}

\section{Giorgia Carolina do Nascimento (IC).}

\begin{abstract}
Resumo
Essa pesquisa apresenta uma análise acerca do quadro de fracasso escolar que atinge o Ensino Médio brasileiro. Partindo de estudo em uma escola pública estadual na cidade de Campinas (SP), esse estudo teve por objetivo investigar a forma como jovens estudantes narram e explicam esse processo.
\end{abstract}

Palavras Chave: Fracasso escolar, repetência, evasão.

\section{Introdução}

Durante o segundo semestre de 2013 foi realizada uma pesquisa de campo em escola estadual, localizada em bairro rural situado no distrito de Barão Geraldo em Campinas (SP), a fim de entender os altos índices de repetência e evasão no Ensino Médio. Esse percurso de observação etnográfica foi percorrido também com o apoio de registros em diário de campo e de entrevistas semi-estruturadas com três jovens estudantes do Ensino Médio.

\section{Resultados e Discussão}

A partir de uma rotina de visitas à escola, foi possível conhecer a instituição e definir os sujeitos a serem ouvidos com o intuito de compreender o processo de escolarização que vivenciaram. Esse trabalho de aproximação permitiu ainda explorar aspectos referentes ao bairro e ao contexto da escola; percepções dos jovens sobre a escola; as relações entre professor e aluno, entre o contexto escolar e o mundo do trabalho, entre o universo familiar; e suas percepções sobre as próprias trajetórias. Além da pesquisa de campo e das entrevistas semi-estruturadas, foram trabalhados dados do IBGE e do MEC, referentes ao tema investigado. Na busca por melhor contextualização da escola, foram utilizados dados da secretaria de educação e material da imprensa local, que permitiram comparações e o entendimento das condições dessa escola em sua articulação com 0 município, o estado e o país.

\section{Conclusões}

Partindo de referencial teórico sobre o tema, verificou-se que, contrariando os dados nacionais - e apesar de haver defasagem com relação à série/idade entre os jovens dessa escola - todos os processos de repetência se deram no Ensino Fundamental, e não no Ensino Médio. Foi difícil conseguir jovens disponíveis para participarem dessa pesquisa. Depois de muita negociação, três jovens foram entrevistados. Além de mostrarem-se dispostos a narrar suas percepções, os entrevistados expressaram o seu contentamento em serem ouvidos. Para os três entrevistados, a escola é uma instituição importante, mas desinteressante, demandando a necessidade de formas diferenciadas de aprendizado que contribuam para a construção de sentidos para o estudo ${ }^{1}$. Na fala desses jovens, é possível compreender que a escola não é apenas um espaço de aprendizagem formal, mas também de socialização. Em torno dele, é construída além de uma relação com o saber, formas de sociabilidade próprias da juventude, fazendo com que a escola já não seja o principal ou o único referencial de formação desses jovens. Além disso, os jovens retratam que professor e aluno pouco se conhecem e que os saberes juvenis são marginalizados. Foi possível observar ainda que muitos jovens são trabalhadores. Todavia, não estabelecem relações entre sua condição de trabalhador e a repetência escolar. Em verdade, constatou-se que os universos da escola e do trabalho não se antepõem, mas se superpõem $^{2}$ e que essas esferas constituem a juventude brasileira ${ }^{3}$.

\section{Agradecimentos}

Agradeço à minha orientadora Profa Dra. Dirce Zan por toda sua dedicação; à direção da escola, que autorizou a realização da pesquisa de campo; aos jovens entrevistados, que com muita disposição cederam suas narrativas e à instituição de fomento CNPq.

\footnotetext{
1. CHARLOT, Bernard. Relação com o saber e com a escola entre estudantes de periferia.

2. DAYRELL, Juarez. A escola "faz" as juventudes? Reflexões em torno da socialização juvenil. Educ. Soc., Campinas, vol. 28, n. 100 - Especial, p. 1105-1128, out. 2007.

3. SPOSITO, Marilia Pontes. Algumas reflexões e muitas indagações sobre as relações entre juventude e escola no Brasil. In: Retratos da Juventude Brasileira - Análises de uma pesquisa nacional. Orgs: ABRAMO, Helena; BRANCO, Pedro Paulo Martoni. Editora Fundação Perseu Abramo, 2005.
} 